Article

\title{
Suburban Infill to Redevelop Suburbia-Retrofitting Post-Suburban Business Locations in the Zürich Metropolitan Area as a Component of Growth Management
}

\author{
Hendrik Jansen \\ Research Group Built Environment, ILS-Research Institute for Regional und Urban Development, 44145 Dortmund, \\ Germany; E-Mail: hendrik.jansen@ils-research.de
}

Submitted: 4 July 2017 | Accepted: 25 October 2017 | Published: 20 December 2017

\begin{abstract}
Regional growth management has become a significant component of sustainable urban land development in many European metropolitan areas. Particularly in rapidly growing metropolitan regions, increasing population and job numbers require strategic planning management, but there is little knowledge about which planning instruments influence or direct these processes most effectively. Based on an analysis of spatial development in the Zürich metropolitan region, particularly in suburban areas, over the past several decades, this article examines the opportunities for the infill, revitalization and retrofitting of suburban business locations as key elements of growth management. In doing so, this article focuses on one central question: To what extent does (cantonal) regional planning and its specific instruments (cantonal structure plan) influence and control the spatial development and urban design quality in the retrofitting of suburban locations? The Glattal region was chosen as a case study as it experienced a significant change in terms of its urban structure during the last 10-15 years. In this context, suburban service locations were examined and analysed in depth using two case studies. The Hochbord area in Dübendorf and the Glattpark area in Opfikon demonstrate the conversion of formerly monofunctional areas (Hochbord) to mixed-use neighbourhoods and the development of new mixed-use locations (Glattpark). The article demonstrates how the suburban office stock transformed to strategic spots for mixed-use in both locations and explores how the retrofitting process could be directed at the cantonal level. In this context, spatial planning instruments at the regional level, such as the cantonal structure plan, seem to play a significant role in the transformation of the urban periphery.
\end{abstract}

\section{Keywords}

growth management; retrofitting suburbia; suburban infill; urban revitalization

\section{Issue}

This article is part of the issue "Garden Cities and the Suburban Antidotes", edited by Markus Hesse and Geoffrey Caruso (University of Luxembourg, Luxembourg).

(C) 2017 by the author; licensee Cogitatio (Lisbon, Portugal). This article is licensed under a Creative Commons Attribution 4.0 International License (CC BY).

\section{Introduction}

In recent decades, many cities across the world with metropolitan functions and regional expansion have experienced a strong influx of people and companies and a concomitant expansion of settlement structures. Recently, these decentralizing tendencies have been characterized by new qualities of suburbanization such as the formation of new centres with functional foci (Brake, 2005; Burdack, 2006; De Jong, 2014; Feindt, 2003; Phelps
\& Wood, 2011). To ensure sustainable spatial development and to prevent urban sprawl, urban and regional planning institutions need to actively control these developments, considering the economic, spatial and design issues in both the densely built areas and the suburban, less densely built areas. From a regional perspective, this results in the increasing importance of entrepreneurial linkages and functional relocations (Hesse \& Leick, 2013). In addition to regionalization tendencies and large metropolitan areas transforming into "polycen- 
tric urban regions" (Kloosterman \& Musterd, 2001; Meijers 2005) or "mega-city regions" (Hall \& Pain, 2009), especially in suburban regions, increasingly differentiated locations have emerged.

Worldwide, suburban locations of the Zwischenstadt ("in-between city") (Sieverts, 1997) consist of the same basic elements (supermarkets, shopping centres, highways, infrastructures, low-density housing), but significant differences appear in their local differentiation (Aring \& Heffert, 2001; Roost, 2013). They often specialize in one dominant field (for example, offices, shopping, housing, trade or leisure) and can be described as "islands with their own profile in a spacious archipelago" (Kunzmann, 2001, p. 214). In recent years, research on the redevelopment and conversion of these locations has increased. Particularly in US discourse, the topic of retrofitting has become an important aspect in the mixing of uses, the legibility of urban structures, the conversion of existing structures and the assessment of public spaces in terms of walkability and landscaping (De Jong, 2014; Dunham-Jones \& Williamson, 2009; Talen, 2011).

Particularly in the past 20 years, many studies have addressed the issue of local and regional growth management in the US (Dempsey \& Platinga, 2013; Landis, 2006; Nelson, 1999), Europe (Bizer, Einig, Köck \& Siedentop, 2011; Bramley \& Watkins, 2014; Kühn, 2003) and Asia (Bengston \& Youn, 2006; Wong \& Lee, 2007; Yang \& Jinxing, 2007). The results go in two directions: while some question the effects of urban growth regulations (land price effects, negative implications on the housing supply, and leapfrogging effects), there is also evidence that urban growth management leads to the spatial concentration of building activity and higher densities in the core areas of cities, thus protecting cultural and natural landscapes (Gennaio, Hersperger, \& Bürgi, 2009; Siedentop, Fina, \& Krehl, 2016). According to Siedentop et al., most studies show that growth management policies are effective but can have negative impacts when poorly managed.

The regional level is of specific importance in the debate of growth management and sustainable urban development here, since policies against urban sprawl and compact settlement structures can be implemented most effectively at this level. Autonomy and power are however, different in each national context (Pallagst, 2007).

Suburban areas can benefit from growth management, particularly since the inward development capacities of many metropolitan areas have been exhausted (Kraemer, 2006). Thus, building reserves in the urban peripheries have to be developed. In the context of European cities, in general, the model of intensification and densification dominates, as expressed, for example, by the Leipzig Charter on Sustainable European Cities (EU Ministers, 2007), in smart growth strategies in North America (Reeds, 2011; Urban Land Institute, 1998) and the Swiss cultural landscape initiative of 2012 in Switzerland (Canton Zürich, 2014; Scholl, 2015). How- ever, strong population growth has led to a lack of available construction sites and building land in many European cities, so spatial planning and urban management need to increasingly focus on suburban areas and their capacities for infill. So far there is little knowledge about the capacities of regional planning instruments and their directing effects on the development of suburban office locations.

Based on previous research on the redevelopment of suburban service areas in the Frankfurt Rhine/Main region, this article examines the metropolitan area of Zürich to determine whether growth management in terms of inner development, structural densification and mixed-use of the core areas offer the opportunity to integrate former suburban locations more effectively into the regional spatial structure and to transform them into more integrated areas. The research on the Frankfurt Rhine/Main region analysed the potential for retrofitting suburban service areas in the region by comparing different urban design instruments at a local level (e.g., zoning plans and design guidelines; Jansen, Wünnemann, \& Roost, 2017). The Zürich metropolitan region serves as an analogous example of how regional planning instruments influence the redevelopment of suburban city structures. Switzerland and the canton of Zürich use specific instruments in the field of growth management at a cantonal level. The canton represents the area of a county, of which 26 exist in Switzerland. The canton has wide-ranging legislative powers and strong political autonomy. This includes the planning of spatial development within the canton. In particular, the instrument of the cantonal structure plan ("kantonaler Richtplan") combined with the regional and local structure plans is of importance here. Its main function is to control spatial development with a definition of the settlement areas (Canton Zürich, 2014).

This article focuses on how regional planning and its specific instruments (structure plans) can contribute to the requalification of suburban locations. Methodologically, it is based on different qualitative approaches that include partially standardized qualitative interviews with key actors at different spatial levels (canton, city and specific locations or projects; $n=15$, see Table 1 ) that were conducted from September to October 2015 and between March and April 2017. Partially structured interviews were chosen, to detect the different views and opinions of stakeholders, especially since the research questions have qualitative foci. The interviews were transcripted, coded and compared in the overlapping areas (e.g., stakeholders from different spatial levels). Furthermore, a variety of planning documents, including the documents to structure planning at the cantonal level and design planning (Figure 3), were analysed and evaluated at the site level. Based on expert interviews, two case studies were identified that were investigated in depth through site visits.

Section 2 describes the growth management of the Zürich metropolitan region and its characteristics as a 
polycentric city region. Section 3.1 analyses the specific development of the Glattal region, which is one of the most dynamic regions in terms of urban development and redevelopment of suburban areas. Sections 3.2 and 3.3 present the results of the case study analysis and empirical findings from the stakeholder interviews. The discussion and conclusion in sections 4 and 5 highlight the effects of the cantonal structure plan on the redevelopment of suburban service locations.

\section{Growth Management of the Polycentric Zürich Metropolitan Region}

The city of Zürich is located in the core of the polycentric Zürich metropolitan region. It has extensive functional and morphological connections to the surrounding communities and regions. Some of the most important areas include the Limmattal, located to the Northwest of the city; the Glattal, located to the North and connected to the Zürich Airport; and the cities of Winterthur and Zug, which are located farther away and serve as financial and service centres (Canton Zürich, 2014). Because of its history as a financial city, the characteristics of the city of Zürich have been shaped by this activity. Since the 1980s, banks such as UBS and Credit Suisse have developed a spatial division of labour and spatial restructuring that were reflected in the site allocation of representative offices and back offices. The consequence of flexibilities such as these caused "fragmented, splintered settlement structures" (Schmid, 2006) with "Business Satellites", the "outer cities", "edge cities" (Garreau, 1991) or "Exopolis" (Soja, 1996). Schmid describes the urban landscape of Zürich as "floating centralities" with the "constant emergence of ever new and surprising urban configurations"

Table 1. List of interview partners.

\begin{tabular}{|c|c|c|c|c|c|c|}
\hline No. & Level & Person & Position & Institution & Project & Interview Date \\
\hline 11 & Cantonal & Wilhelm Natrup & $\begin{array}{l}\text { Head of Department for } \\
\text { Spatial Planning }\end{array}$ & Canton of Zürich & Various & 07.10 .2015 \\
\hline 12 & Cantonal & Mathias Loepfe & $\begin{array}{l}\text { Employee at the Regional } \\
\text { Planning Association Zürich }\end{array}$ & $\begin{array}{l}\text { Raumplanung Zürich } \\
\text { and Umgebund }\end{array}$ & Various & 10.10.2015 \\
\hline 13 & Local & Pascal Hunkeler & $\begin{array}{l}\text { Head of Urban Design } \\
\text { Department }\end{array}$ & City of Zürich & Various & 08.10 .2015 \\
\hline 14 & Local & Anna Schindler & $\begin{array}{l}\text { Head of Urban } \\
\text { Development Department }\end{array}$ & City of Zürich & Various & 26.10 .2015 \\
\hline 15 & Local & Marco Forster & $\begin{array}{l}\text { Employee in the Planning } \\
\text { Department }\end{array}$ & City of Dübendorf & Hochbord & 28.10 .2015 \\
\hline 16 & Local & Nils Epprecht & $\begin{array}{l}\text { Employee in a planning } \\
\text { office }\end{array}$ & Office SAW & Hochbord & 30.10 .2015 \\
\hline 17 & Local & Roland Stadler & $\begin{array}{l}\text { Employee in the Planning } \\
\text { Department }\end{array}$ & City of Opfikon & Glattpark & 23.10.2015 \\
\hline 18 & Science & Michael Koch & Professor for Urban Design & HCU Hamburg & Various & 27.10 .2015 \\
\hline 19 & Science & Simon Kretz & $\begin{array}{l}\text { Research Associate at } \\
\text { Institute of Urban Design }\end{array}$ & ETH Zürich & Various & 12.10 .2015 \\
\hline 110 & Local & Reto Lorenzi & $\begin{array}{l}\text { Head of Planning } \\
\text { Department }\end{array}$ & City of Dübendorf & Hochbord & 01.04 .2017 \\
\hline I11 & Local & Vinzenz Zedi & $\begin{array}{l}\text { Head of Project } \\
\text { Development }\end{array}$ & Mobiliar AG & Hochbord & 10.04.2017 \\
\hline 112 & Local & $\begin{array}{l}\text { Walter } \\
\text { Mosimann }\end{array}$ & Board of Interest Group & $\begin{array}{l}\text { Interest Group } \\
\text { Hochbord }\end{array}$ & Hochbord & 26.04.2017 \\
\hline 113 & Local & Roland Stadler & $\begin{array}{l}\text { Employee in the Planning } \\
\text { Department }\end{array}$ & City of Opfikon & Glattpark & 26.04.2017 \\
\hline 114 & Local & $\begin{array}{l}\text { Johannes } \\
\text { Eisenhut }\end{array}$ & $\begin{array}{l}\text { Head of Project } \\
\text { Development }\end{array}$ & Senn Resources AG & $\begin{array}{l}\text { Glattpark/ } \\
\text { Hochbord }\end{array}$ & 07.04.2017 \\
\hline 115 & Local & $\begin{array}{l}\text { Bernhard } \\
\text { Ruhstaller }\end{array}$ & Managing Director & $\begin{array}{l}\text { Development } \\
\text { Agency Glattpark }\end{array}$ & Glattpark & 05.04.2017 \\
\hline
\end{tabular}


(2006, p. 163). This development of Zürich settlement structures followed the economic concept of "flexible accumulation" in post-Fordism described by Harvey (1985, 2016). This refers to the division of work processes and their spatial characteristics. In the metropolitan area of Zürich, these developments led to a strong polycentric structure with numerous business locations in peripheral locations. Examples include, among others, the Cherstraße office park in Zürich-Kloten, the Hochbord industrial area in Dübendorf and the Leutschenbach office park. All these sites originated from former industrial areas that were gradually transformed to service facilities during the 1970s and 1980s and comprise areas between 25 ha and 35 ha.

Due to a prosperous economy, high quality of life and political stability, the metropolitan area is currently experiencing a strong growth phase. Between 2005 and 2010, the metropolitan area experienced a population growth of 100,000 inhabitants and, as of 2015, over 400,000 people live in Zürich and approximately 1.7 million people live in the Zürich metropolitan region (Canton Zürich, 2014). The number of inhabitants in the canton of Zürich is expected (mid-range scenarios) to increase by approximately 600,000 by 2030 (Canton Zürich, 2014; 17, 2015). The city of Zürich is expecting an increase of approximately 80,000 inhabitants and as many jobs by 2030 . Additionally, the more peripheral or suburban city areas, such as the Glattal and Limmattal regions, are experiencing strong growth.

The development of today's polycentric structure in the Zürich region with the aforementioned phenomena of suburbanization and job relocation in the suburban area was accelerated by the expansion of S-Bahn train connections at the beginning of the 1990s, particularly in the areas of Limmattal and Glattal (Kretz \& Küng, 2016; 14, 2015). The additional permission for service uses in industrial zones was a response to the economic crisis, which resulted in the transformation of areas such as those in Zürich-West and Zürich-Oerlikon (13, 2015; 17, 2015). Expansion of the railway infrastructure also led to a new functionalization of the linked locations. The network evolved from industrial suppliers (especially freight) to employment suppliers (passengers) for growing use for service jobs. These jobs led to increased demand for residential uses and consequently increased settlement activity in these suburban areas (Kretz \& Küng, 2016). Strong economic growth in recent decades resulted in some conflicts in cantonal and municipal spatial planning surrounding subjects such as sprawl, compactness, mixed-use and protection of cultural and natural landscapes:

The cities in the canton of Zürich have to demonstrate strategies for how they increase density and develop the inner-city areas, especially the building zones ("Bauzonen") that have not been fully developed yet. They also have to prove densification strategies such as built-up storeys of existing buildings. The city of Zürich has rather low densities compared to cities such as Munich, Frankfurt or Basel, which are much denser. The inner-city areas have a great deal of potential for the future. $(17,2015)$

As a result, the "Kulturlandinitiative" (Cultural Land initiative) was adopted as a result of a referendum with $54.5 \%$ of positive votes in 2012 . This initiative provides active protection of agricultural and ecologically valuable areas (Canton Zürich, 2014).

Suburban areas are subjects of intense discussion at various Swiss planning levels. The guidelines for action of the cantonal structure plan in the field of "urban landscape" seek higher densities and mixed-use. These guidelines should strengthen the city by shortening distances and ensuring accessibility to public transport. The "Kulturlandinitiative" was a revision of the Spatial Planning Act and thereby further legitimized enhancing control of spatial development of the canton of Zürich. In fact, it accelerated the Spatial Planning Act in 2013. The revision of the cantonal structure plan defines containing $80 \%$ of the population growth in already densely built-up areas as the main strategy for the Canton of Zürich. This follows the Leitmotif "inward development before outward development" which is a central part of the Swiss Spatial Planning Act that came into force in 2013. In Switzerland the cantonal structural plans are the main instruments to lead the spatial development (not national concepts or local zoning plans). This is not a new tendency but a wellaccepted basis for spatial development since the 1980s.

With the "Kulturlandinitiative" and the Spatial Planning Act in 2013, the Zürich metropolitan region is following a planning policy that is similar to many other regions in Germany (described in Bundesinstitut für Bau-, Stadt- und Raumforschung [BBSR], 2017) or Austria (described in Österreichische Raumordnungskonferenz, 2011). In order to reduce the consumption of land for new development and to preserve natural resources, future settlement development is supposed to be compact and should focus on inner city areas before outward city ones.

The central planning tool for the management of sustainable spatial development of the canton of Zürich is the cantonal structure plan. This is an instrument for early information and allows for the participation of the population. Therefore, it moderates possible conflicts with the public interest (Canton Zürich, 2014). The structure plan is the leading instrument in combination with regional and local master plans. It addresses the topics of spatial development, settlement, landscape, traffic, supply/disposal and public buildings and facilities and operationalizes them in targets, maps and actions. In relation to urban development, the structure plan defines the socalled central areas of which there are currently twelve in the metropolitan area of Zürich.

Central areas are settlement centres of cantonal importance in the fields of education, culture and economics as well as areas with particular potential for trans- 
formation. The cantonal structure plan includes mandatory requirements for authorities at all levels (cantonal, regional, local) but does not define restrictions on exact parcels of land or for landowners. The specifications of these requirements of the structure plan are usually developed at the local level through zoning and possibly design guidelines or building regulations (Canton Zürich, 2014; 17, 2015).

\section{Development of the Glattal Region}

The Glattal region in Zürich-North demonstrates growth management in suburban areas, and it serves as a prototype for development outside the core city of Zürich $(15,2015)$. The region has received special attention in literature in recent years (among others Architekten- gruppe Krokodil, 2013 and Schmid, 2006). The Glattal region consists of eight autonomous communities (Rümlang, Kloten, Opfikon-Glattbrugg, Wallisellen, Bassersdorf, Wangen-Brüttisellen, Dietlikon and Dübendorf) and connects to Zürich-Downtown and Zürich-Kloten spatially and functionally (Figure 1).

Because of its strategic location, the region has had a strong influx of people and jobs with increased infrastructure and settlement developments since the 1990s/2000s (Odermatt, 1999). The Glattal region is referred to as "mature suburbia" and has evolved from urban fragments into an urban structure (Campi, Bucher, \& Zardini, 2001). This has recently led to major urban densification and restructuring in many places, resulting in municipalities merging into a regional "Glattstadt" (Campi et al., 2001; 13, 2015; 18, 2015). Due to these dynamics,

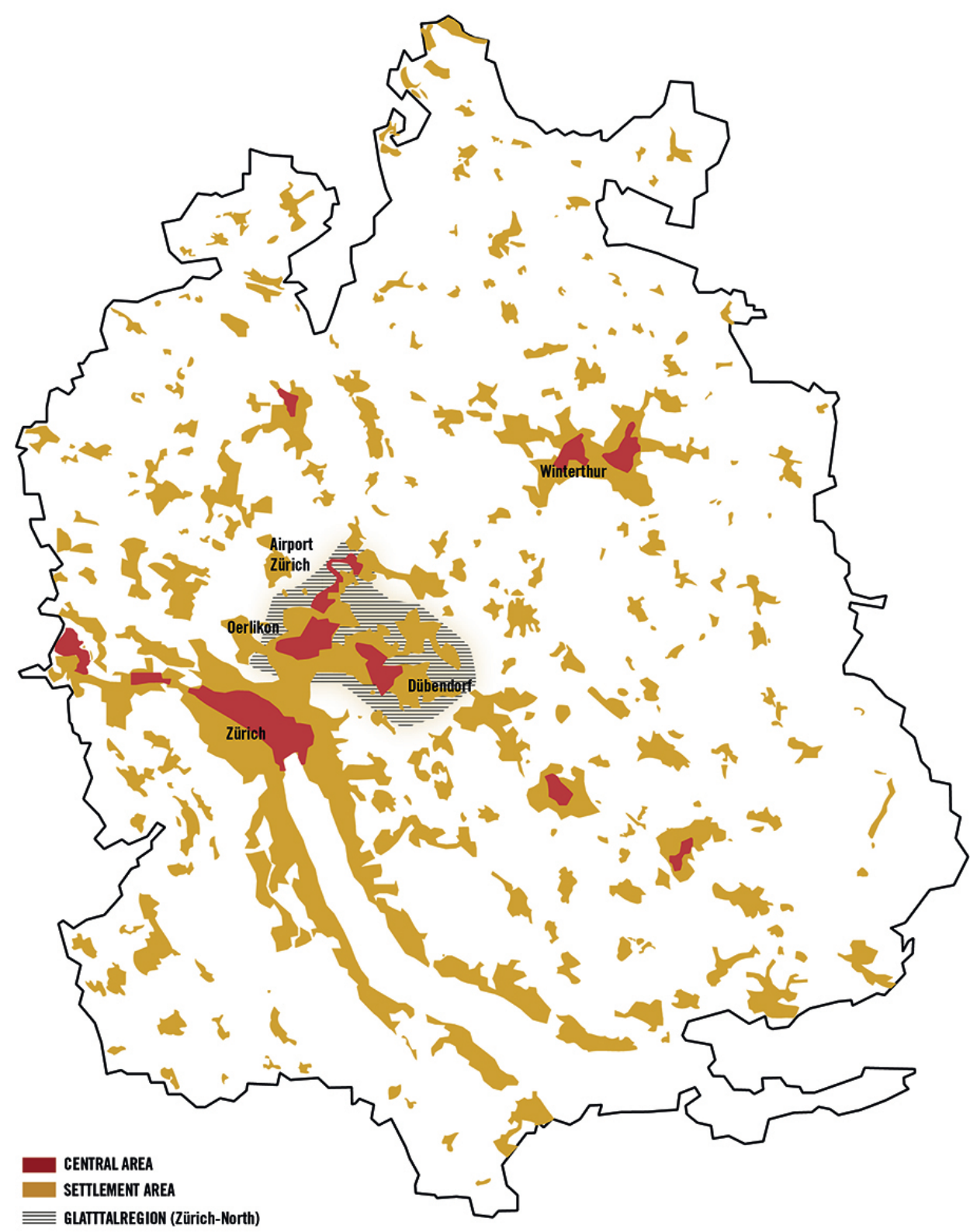

Figure 1. Overview of the settlement structure and central areas in the Zürich metropolitan area and the location of ZürichNord/Glattal area. Source: author based on Canton Zürich, 2014. 
Zürich-North is also called the "secret capital" (Loderer, 2001), indicating that physical change is much more visible here than in the core city of Zürich itself.

This increasing focus on the transformation of suburban housing developments in the city of Zürich and the Glattal region, however, is not an isolated case in Switzerland. Meili comments, "Essentially, Zürich and Basel no longer have any insoluble problems in their own urban territory. All Swiss cities have a problem of form outside the city core" (Meili, 2013, p. 3).

From 1980 to 2013, population increased by approximately 50,000 inhabitants to a total of approximately 160,000 in the upper Glattal region. The number of employees rose to approximately 65,000 . By 2030 , another estimated 30,000 residents and 25,000 employees are expected to migrate to the area. In the mid-term, the area will have approximately 190,000 inhabitants (Kretz \& Küng, 2016). In particular, the region's infrastructure (airport and railway) and low business taxes are reasons for this development, which has led to the formation of suburban service centres with numerous back offices of banks and insurance companies (Kurz, 2008; Odermatt, 1999). These suburban service locations in the Glattal region correspond with the definition of what Brandl, Barman-Krämer and Unruh called "super com- plexes", which they described as "regions implanted into the urban fabric" and characterized as "collections of large detached buildings of consumption, leisure or service sectors that shape the urban space through symbolic elements" (2007, p. 47). Therefore, these sites have high importance both in functional terms and as design elements of suburbia.

Kretz and Küng remarked that many of these places are the most dynamic in the Glattal region (e.g., Cher in Opfikon, the Glatt/Grindel district in Wallisellen) and described them as "inner peripheries" or "outer centralities" of the region, meaning that these areas are peripherally driven even though they are topographically within the booming region (Kretz \& Küng, 2016; 19, 2015). The Glattal region represents the starting point of the metropolitan region of Zürich for a successive suburban redevelopment and thus provides a new approach in the Swiss retrofitting debate (Campi et al., 2001; Pfenninger \& Schregenberger, 2013).

The canton has reacted to this growth in the structure plan and defined three of the central areas described above in the Glattal region: northern Zürich/Opfikon, Kloten/Opfikon and Wallisellen/Zürich/ Dübendorf-Stettbach (Figure 2). All of these regions are classified as "development areas" (Canton Zürich,

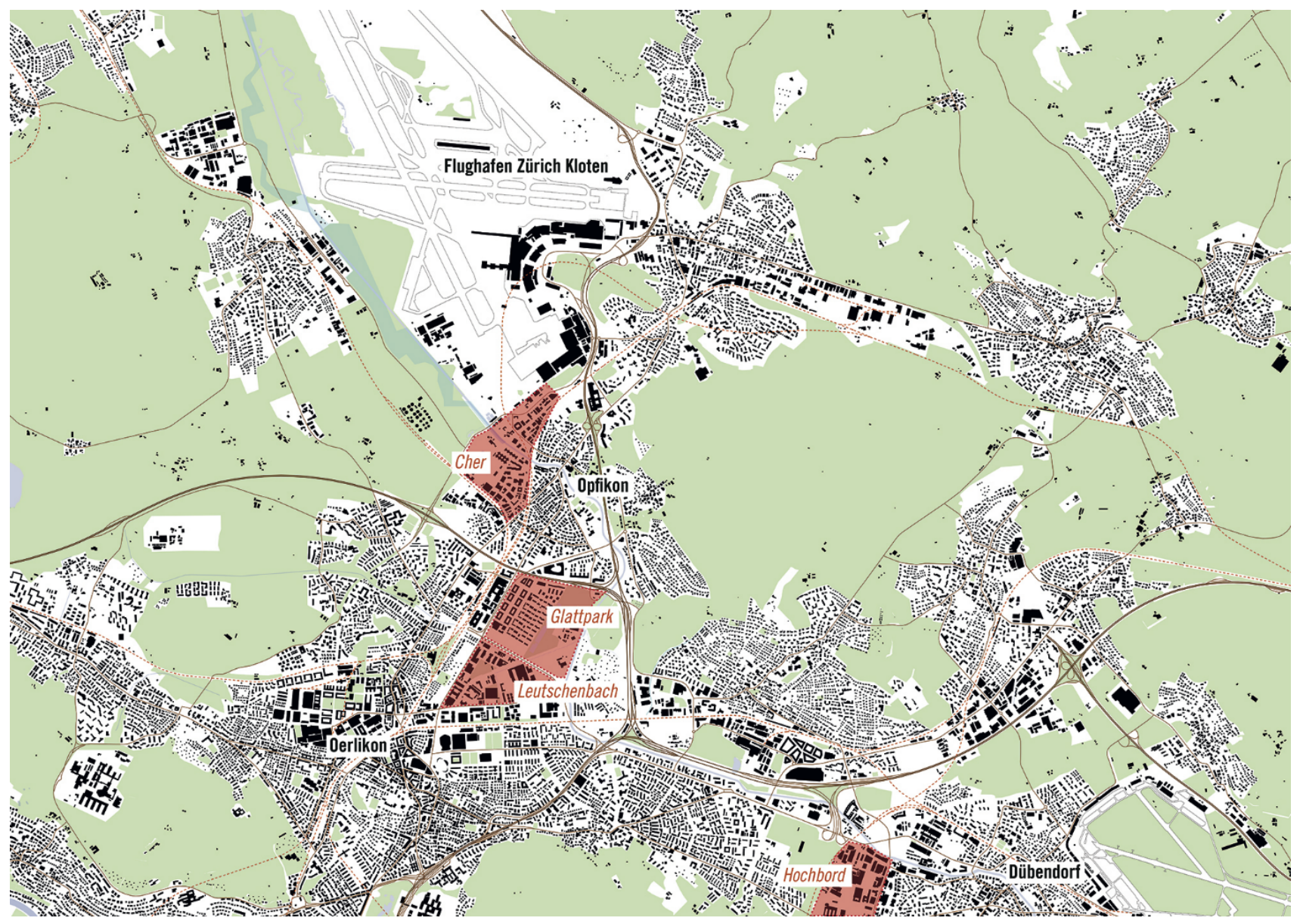

Figure 2. Building structure and infrastructural connections in the Zürich-Nord/Glatttal Region with suburban office locations Cher, Glattpark, Leutschenbach und Hochbord. Source: author based on Kretz \& Küng, 2016. 
2014). The development objectives for these central areas are supposed to be mixed-use, densification and increased infrastructure development (transport and green spaces):

The city of Zürich tries to keep a 1:1 ratio between jobs and residents, which has proved to be healthy for urban development. However, right now, there is a much higher demand for housing developments. $(16,2015)$

These central areas currently include numerous suburban service locations, which are usually characterized by being low density, structured in a mono-functional manner and having poor urban quality in terms of open space and building structure. They are currently undergoing an intense retrofitting process, which is affecting architectural and urban conversion, additional uses and improvement of public spaces. In particular, opportunities for growth management manifest at the urban level of the district. Here, both structural and social transformation processes can be observed, and their spatial effects can be analysed. This is done in the following two case studies of the Glattal region.

The cantonal level has two main responsibilities that can effectively control and shape the development and retrofitting of these suburban service locations:

1. The definition of central areas

With its main instrument, the cantonal structure plan, the canton is able to define areas of "cantonal importance". These areas are described as areas with high density, mixed-use, proportional ratio between jobs and residents and very high quality of transport infrastructure. By defining these ar- eas, the canton commits to public investment in transport infrastructure. Within this category, real estate developers can rely on long-term planning security for their projects and are more likely apt to invest. The definition also influences the image of an area in a long-term perspective (I10, 2017; I11, 2017; I14, 2017).

2. The permission of building activity

Within the Zürich metropolitan area, the canton of Zürich with its Department of Spatial Planning is the permission-giving authority for any building activity. This means the planning sovereignty is on a regional level (cf. Figure 3). In this sense it can demand certain quality assuring instruments such as a Testplanung ("test planning process"), Sonderbauvorschiften ("special building permits") or Quartiersplanpflicht ("neighborhood design plan obligation"). All these instruments affect the development of the built environment. If cities or developers do not cooperate the canton may deny the building permit, which is rarely the case $(110,2017$; I11, 2017; I14, 2017).

However, the cantonal structure plan can "only" create a framework of conditions (i.e., define the central areas, uses and densities, demand detailed studies), as it is binding among all subordinate authorities (16, 2015; 17, 2015; I10, 2017). The execution of building activities is still in the responsibility of the city.

\subsection{The Hochbord District in Dübendorf}

The example of the Hochbord district in the municipality of Dübendorf exemplifies opportunities for urban transformation in suburban service locations. This area is lo-

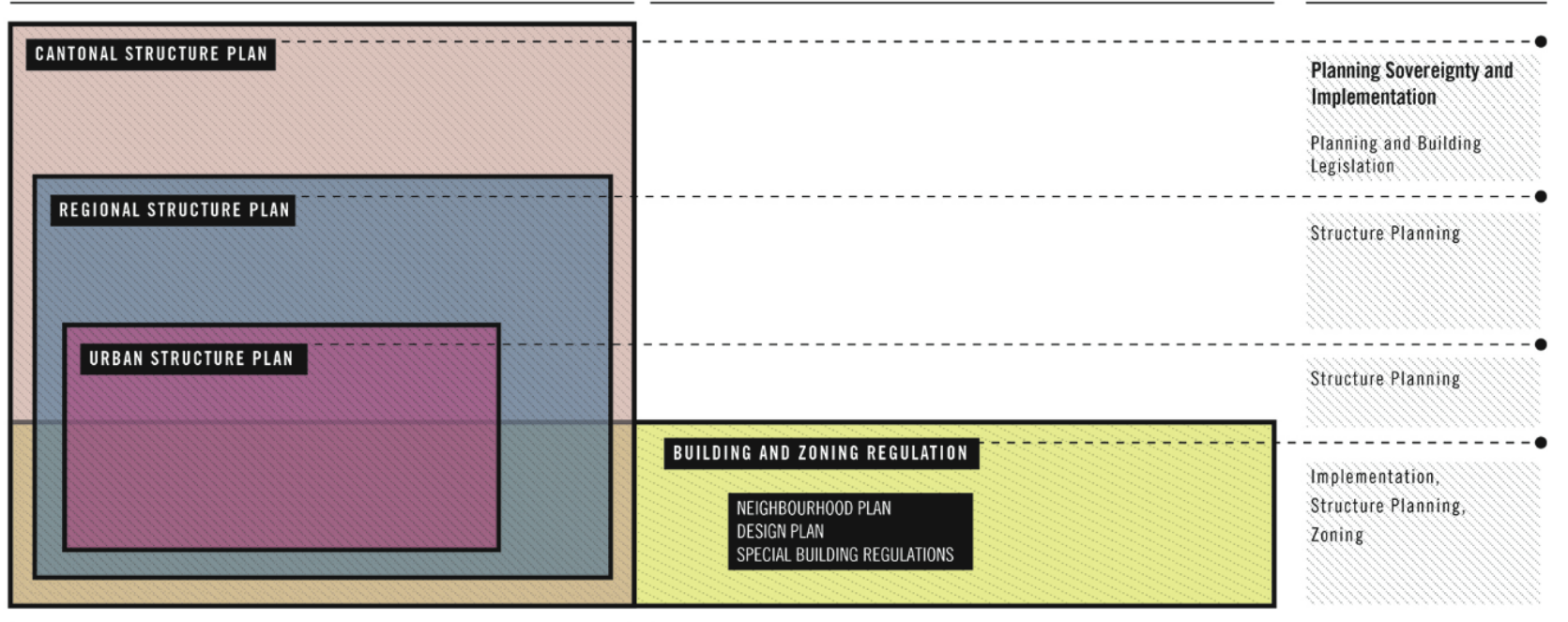

Figure 3. Competences and bindings of different planning instruments on cantonal, regional and local level for the Canton of Zürich. Source: author based on Hoelzel, 2014. 
cated Southwest of the centre of Dübendorf $(26,000$ inhabitants) and has a size of approximately 36 ha with predominantly commercial uses. Via the Stettbach public train station, the area is connected to the Glattalbahn, which reaches the Zürich Airport as well as the city of Zürich and other communities in the Glattal region. There is also a connection to the A1 highway which links to Winterthur and Zürich. The Hochbord region was an industrial zone on the outskirts of Dübendorf in the 1930s and was used for this function for many decades. Due to a decline in demand for industrial and commercial areas in the 1980s, not all areas were completely developed.

With increasing pressure on the housing market in the Zürich region and the convenient access to the public transport system, in the late 1990s, the area was designated as a central area in the cantonal structure plan (Figure 4) and was therefore considered to be a "settlement area of cantonal importance". This planning target served as a strong restructuring step that provided appropriate density and mixed-use $(17,2015)$, highlighting its importance as "residential use as an impulse". The maximum share of residential use was determined by the Department of Spatial Development to be $60 \%$. Subsequently, the city of Dübendorf and the Suter von Känel Wild (SKW) urban planning office created a neighbourhood concept in 2003 that represented the main architectural structures, open spaces and transport infrastructure. The canton and the municipality agreed on a design plan obligation for the entire territory of Hochbord to ensure appropriate urban design quality (SKW, 2015; Figures 5 and 6).

The municipality expects approximately 10,000 new jobs and approximately 900 new inhabitants for the area. The proposed designs of the municipal structure plan and the district plan are based on block development and produce high density. The plan also provides a balanced distribution of residential units and generates a higher percentage of living areas in the quieter inner parts (Figures 5 and 6). These plans are binding for all landowners and specify the requirements of the cantonal structure plan at the municipal level $(12,2015 ; 17,2015)$. A 100meter high residential tower is one of the remarkable urban development projects: the Jabee Tower, with 212 apartments, serves as both a modern residential building with delightful views of the Glattal region and a landmark for a new centre of the neighbourhood. Critics of this project from the general public noted a lack of scale and focused on the expected traffic congestion in the area $(I 1,2015)$, although it has to be noted that the densities meet existing planning laws with Hochbord as a central area.

As part of the restructuring process, the Hochbord interest group (IG) was established in 2009. It consists of numerous local companies and participates in the development process of the site on an informal basis. Conflicts in the Hochbord area mostly arise because of

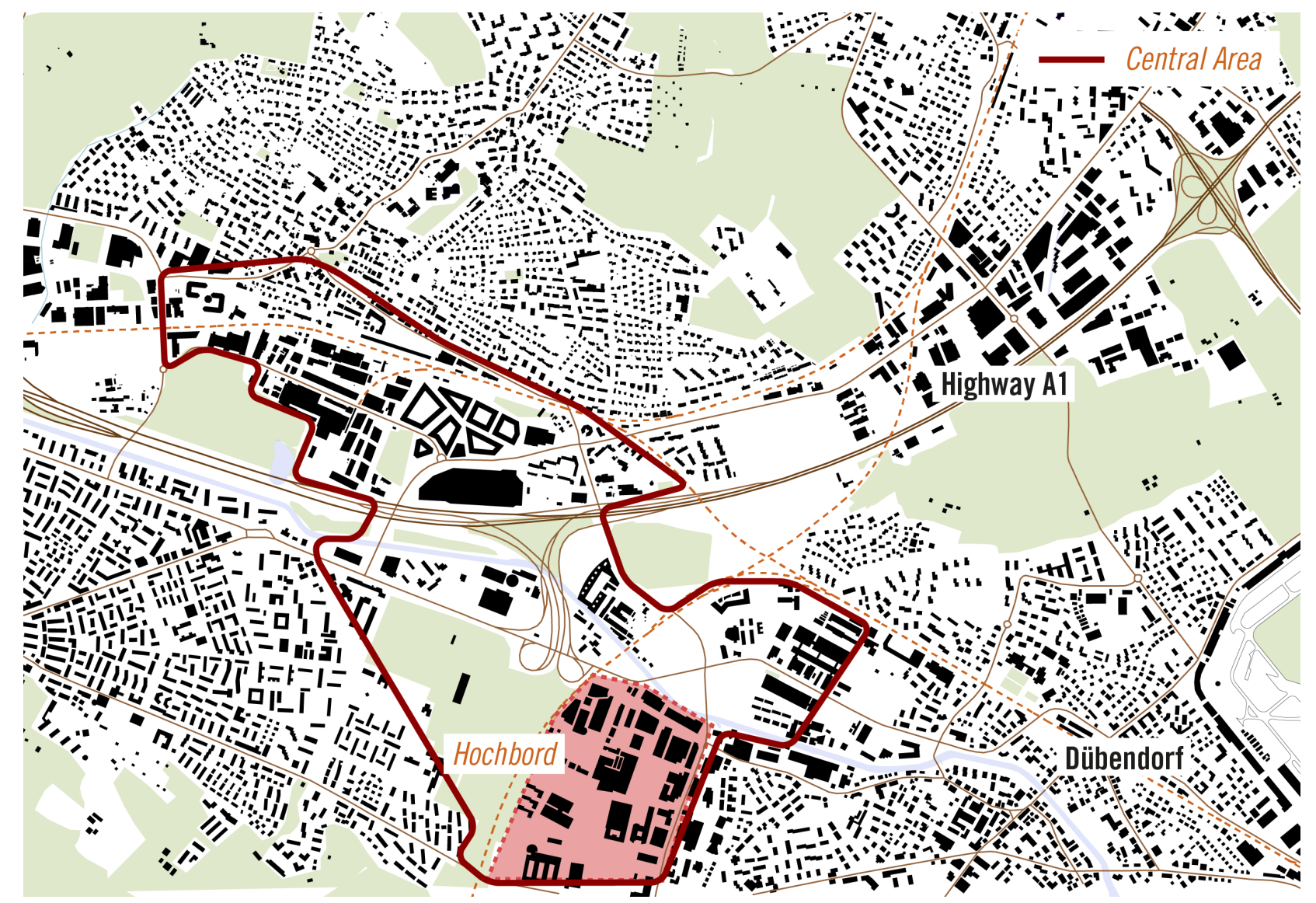

Figure 4. Definition of central areas in the Glatttal including the area of Hochbord in Dübendorf. Source: author. 


\section{COGITATIO}

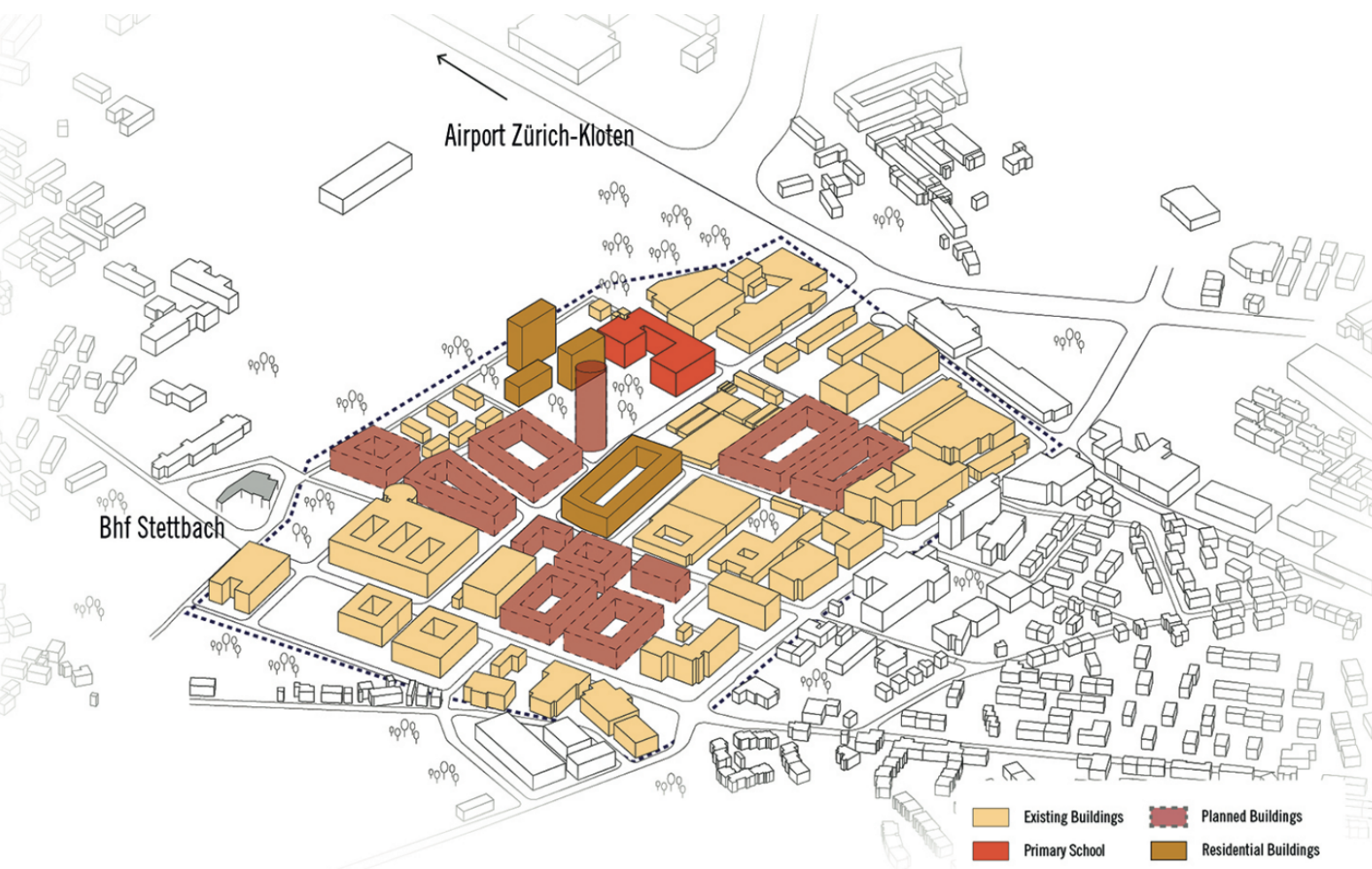

Figure 5. Building structure and distribution of uses for the case study of Hochbord in the city of Dübendorf: the existing commercial and office buildings are complemented by mixed-use typologies and housing. Source: author.
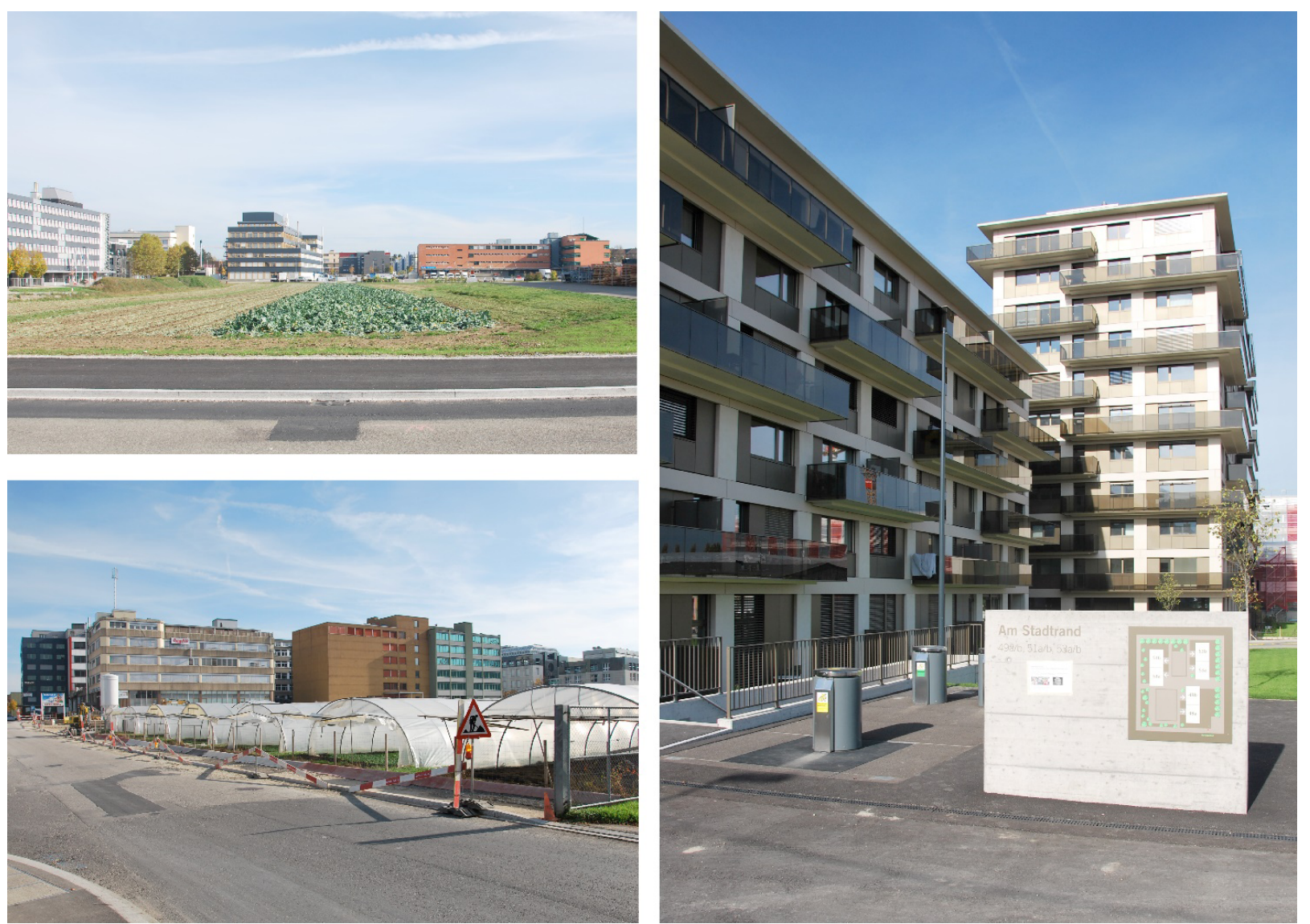

Figure 6. First building projects for the restructuring of the Hochbord area are already completed and represent high density housing projects. Source: author. 
the fragmented structured ownership. According to 12, some landowners see the potential for the development of their land and encourage rapid development. Others, however, fear a restriction of the expansion potential for commercial use and interference in the development through legal actions $(12,2015 ; 112,2017)$. Due to a strong private development dynamic the Hochbord interest group has changed its status from a protective organisation of private land owners towards an economic and cultural support organization of the area (I12, 2017), since the Hochbord area has become a significant cultural, residential and business spot even on a regional scale.

Overall, the restructuring of Hochbord has been much slower than that of Glattpark in Opfikon (see case study 2). According to Forster (I5, 2017), this slower development may have advantages, as more organic growth is possible and potential impacts of ongoing construction projects on the whole project can be responded to individually. Because of the strong structural densification, the Hochbord area will serve as a "new" centre of Dübendorf $(12,2015)$, which might facilitate functional shifts to today's Dübendorf downtown. These are, however, not yet achieved, as both the companies and the new residents are more strongly connected to the city of Zürich than the city of Dübendorf.

For private real estate developers, there are different reasons to develop property in the Hochbord area. Quite notably, the definition of Hochbord as a central area in the cantonal structure plan is not experienced as important factor for investment decisions (I11, 2017; I14, 2017). It does have an indirect effect though, since all interviewed real estate companies named as the first and most important reason for investment the high quality of public transport infrastructure $(I 11,2017 ;$ I14, 2017). In this sense, the cantonal structure plan can create planning security for investors, as they can trust on robust transport infrastructure development by the canton, parallel to their real estate investments.

For the city of Dübendorf the cantonal level has a direct influence on the Hochbord development, since it can deny building permission, if design and concept are not to its full satisfaction. In the case of Hochbord the canton demanded a clear concept of residential-share in each building parcel, asked for a definition of important ground floor areas with activating uses (such as restaurants, shopping or leisure) and stated the necessity of a neighbourhood design plan (one of Zürich's urban design tools to create a detailed plan on the local level). These aspects demonstrate the strong influence of the cantonal level on the development of the Hochbord area (I11, 2017; I14, 2017).

\subsection{The Glattpark Area in Opfikon}

The development of the Glattpark area is an example of transformation that occurred due to suburban densification and development planning in the Glatt region. The first plans for the development of the former agricultural area were initiated in the 1950s. The first district plan from 1957 provided a designation of approximately 66 ha of land to be developed as dense service areas to create 15,000 jobs. Previously, this area was purchased by the city of Zürich and was supposed to serve as an outsourcing area for public buildings.

The 1961 zoning plan with an outstretched industrial sector was approved but never realized. The second district plan, which was completed by the city of Opfikon in 2000, was designed as a mixed-use area for approximately 6,600 residents and 7,300 jobs. The plans for the realization were set for 3 development zones, which have mostly been completed (Figure 7).

The first zone provides a service area, which is right on the main street (Thurgauerstrasse) and is less sensitive to noise emissions from transport and traffic. Some international companies, such as Mondelez and Takeda, have already settled here. The second zone provides space for a mixed-use and supply area, which can also be seen as the centre of Glattpark connecting a central district street with the "Boulevard" leading from South to East. The third zone is the residential area, which is almost completely realized as block structures. The highdensity housing forms have a strong connection to the Glattpark green area in the east by visual connections and structural orientation of the buildings towards this open space. This forms a generous open space and creates amenities for the residents. In conclusion, Glattpark has a very urban textured image, with a focus on classic block development and multi-storey buildings (Figures 8 and 9).

Both zoning and urban design principles are therefore defined by the design regulations of special building regulations (including statements on urban principles, phased development, the distribution of uses and elevated ground floors). In the three development zones, the number of floors in the buildings is regulated as follows: five-storey buildings in the residential section, sixstorey buildings in the mixed-use section and up to sevenstorey buildings in the service section (Figures 8 and 9). The Glattpark project is an example of a long-term negotiation process with a relevant initiative of the citizenry. The rethinking of urban planning was, however, only manifested by societal protest movements and may be considered (as stated in Schmid, 2006) as a blueprint for the culture of participation in the planning processes in Switzerland (Kretz \& Küng, 2016; Schmid, 2006). Despite intense planning, structuring and urban design regulations, the density of buildings and the influx of a large number of new residents in Glattpark led to social conflicts. The inhabitants of the new Glattpark district differ strongly in their milieu and lifestyle from the inhabitants of Opfikon and usually have a much stronger link to Zürich's city centre than the centre of Opfikon (I5, 2015; 16, 2015). This has led to numerous community workshops and participation formats in which the different groups were urged to reach consensus and to develop greater understanding of the developments in Glattpark 


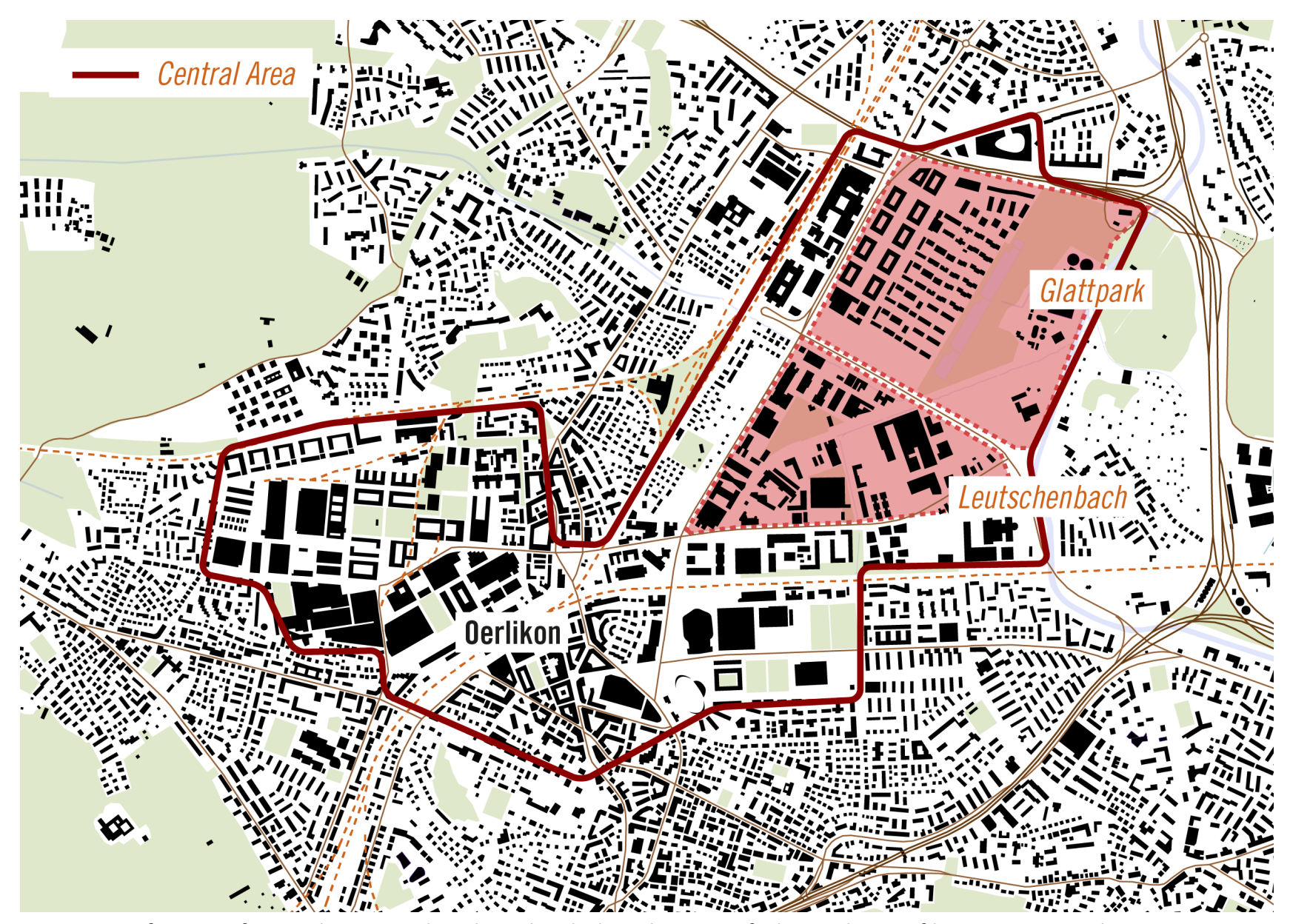

Figure 7. Definition of central areas in the Glatttal including the area of Glattpark in Opfikon. Source: author.

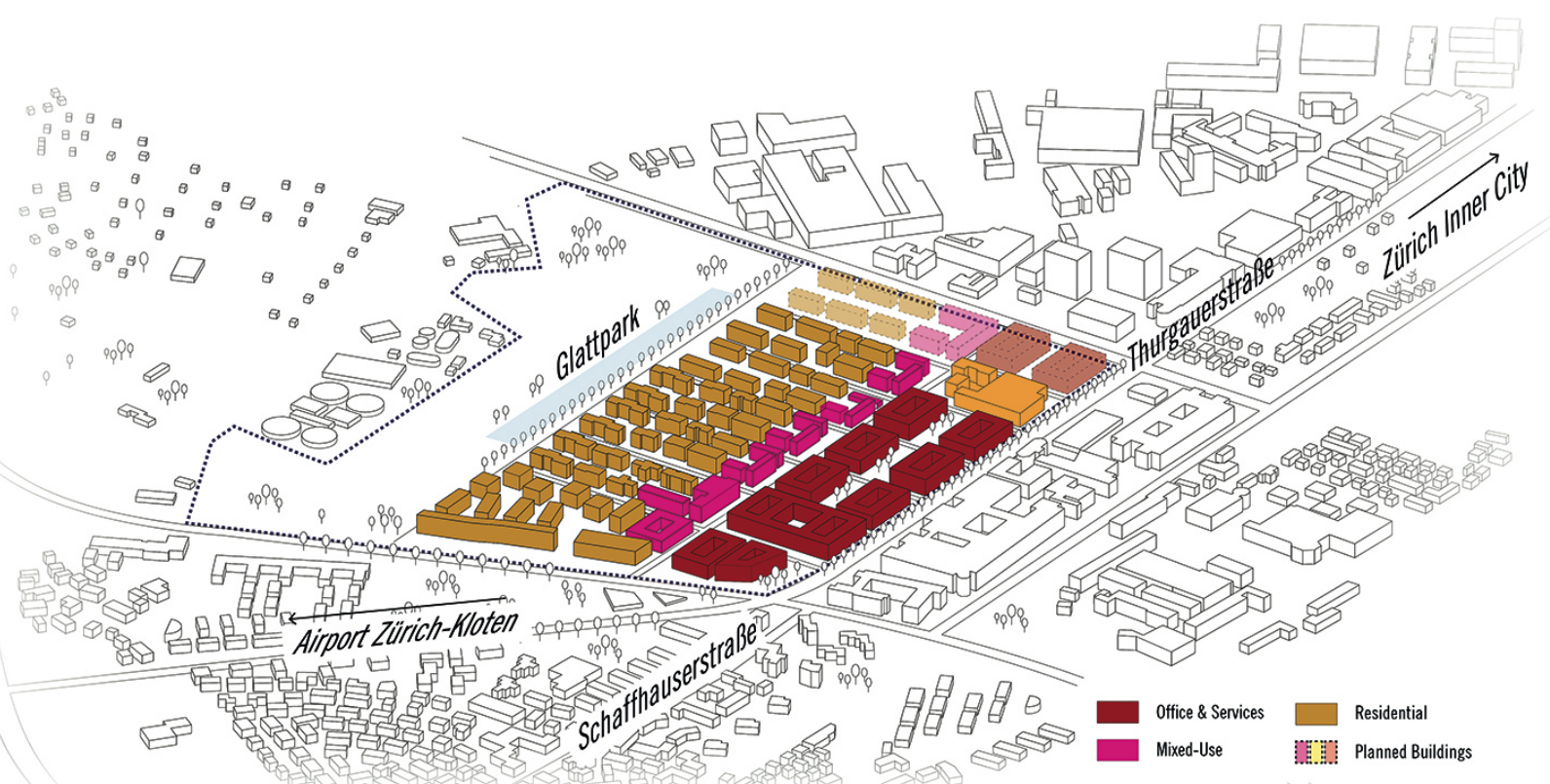

Figure 8. Building structure and distribution of uses for the case study of Glattpark in the city of Opfikon: strong zoning restrictions and high urban densities for office and residential uses. Source: author. 

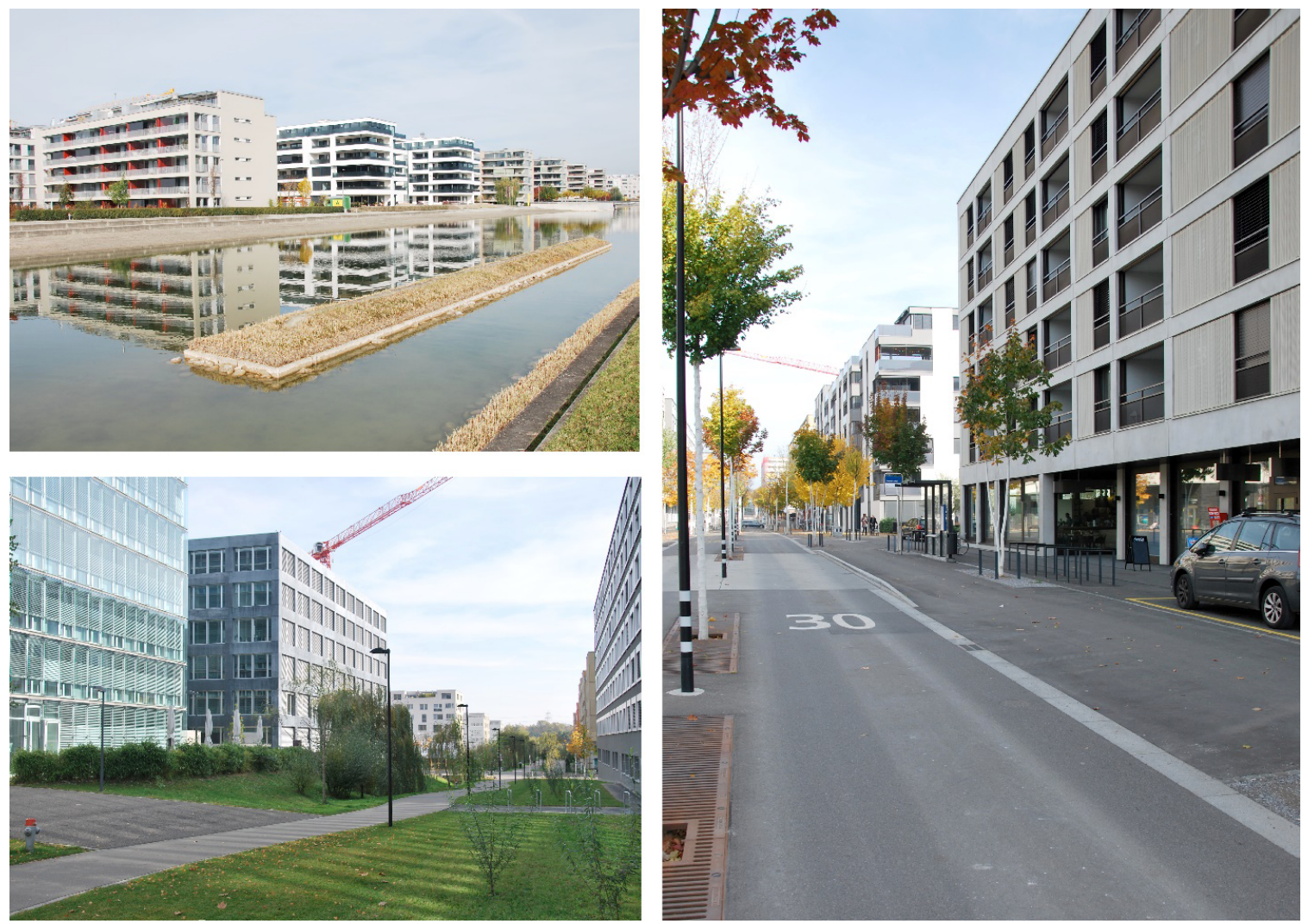

Figure 9. The three defined zones show the building design and design of public spaces in the case study of Glattpark. Source: author.

and the adjacent Leutschenbach office park, which was part of the development $(16,2015)$.

The Canton of Zürich has defined the Glattpark area, which is a part of the bigger Zürich North area, as a central area of cantonal relevance since 1999. Beside the investment and building in the Glatttal train, that is connecting the area to Zürich's inner city and the airport, the canton has influenced the development of the Glattpark by the definition of "special building permits" and a "neighborhood design plan obligation". Both instruments helped to structure the area and ensure high urban design quality. The neighborhood design plan helped to establish a public park area, the Glattpark. The special building permits controlled the establishment of the central street (Boulevard) and its distribution of uses. This included the heights of ground floor areas and the establishment of an office zone along the Thurgauerstraße (see Figures 8 and 9; I13, 2017; I15, 2017).

Similar to Hochbord area, the Glattpark area benefits from the strong connection to public transport and its outstanding location between the inner city and airport, which are compelling arguments for investment (I13, 2017; I14, 2017; I15, 2017).

\section{Discussion}

The Glattal development and the case studies presented demonstrate the effects of specific planning instruments on transforming suburban locations in the canton of
Zürich (Figure 8). Infill and strong growth offer an opportunity for the redevelopment of suburbia and can transform suburban service centres. The high pressure in the housing market led to a "forced retrofitting" of these locations, with the infill and integration of mixed-use building structures as well as higher densities. The cantonal structure plan is an aligned consensus instrument that, together with the municipal offices (e.g., Department of Urban Design, Department of Urban Development) of Zürich and surrounding communities, can facilitate the long-term development of the region.

To secure urban design qualities, municipalities can use the instruments of building and zoning regulations, building codes and design plans or design guidelines to control the concrete building form. The canton defines the central zones in a dialogue with the municipalities. While the municipalities have to develop the areas according to the central zone characteristics (e.g., density and mixed-use), the canton has an obligation to establish the road infrastructure and connection to public transport hubs. Being permission-giving authority for the Swiss zoning plan ("Bau- und Zonenordnung"), the canton can force a retrofitting of specific areas within the metropolitan area.

Zürich has only a few mono-functional suburban office locations. That is probably because the planning sovereignty is on the cantonal level, while the implementation sovereignty is on the local level. $(16,2015)$ 
The structure plan provides the development of densification and mixed-uses, especially in places that have good regional transport infrastructure. Both case studies demonstrate that the Glatttalbahn can be seen as a key driver of development for the entire region, which simultaneously promotes and manages growth. However, in the development of the respective locations, the ownership structures played a crucial role. The cantonal structure plan therefore prevents "planning that stops at community borders" and may also play a part in influencing urban design and quality $(12,2015 ; 113,2017)$. The major development areas found in both Dübendorf and Opfikon occur "on the edge" of the city. From the perspective of the metropolitan region and the canton, these areas are key growth areas $(12,2015 ; 17,2015)$.

In the case of Glattpark Opfikon, the city owns the whole area, which greatly accelerated development dynamics, marketing and implementation of the provisions of the cantonal structure planning. The fragmented distribution of land owners in the Hochbord area required a longer negotiating process in the land development.

However, the presented case studies also show how the densification and change of use can lead to conflicts in some areas, which can be caused by both the structural form (extreme densities and atypical typologies in a location; Lampugnani, 2015) and the social structure (divergence of local residents and new inhabitants; 15, 2015; 16, 2015; I10, 2017). Interviewees mentioned a decoupling of the connection between new residents and old residents in terms of their social status and lifestyle. Additionally, the interviewees for Hochbord mentioned, how existing companies (e.g., crops producer), might be forced to relocate and leave the area due to emissionconflicts with the upcoming residential uses.

These tendencies can be examined in both case studies. It is an open question whether in the long-term the mixed-use of this location will lead to positive effects on the quality of the area and contribute to stronger integration. The need for strong growth management in Switzerland and Zürich has led to the establishment of appropriate land-use planning tools and a systematic restructuring of suburban locations. In these cases, the regional instrument of the cantonal structure plan is an effective tool in terms of the spatial allocation of densification, mixed-use development and urban integration, particularly for developing suburban areas and thus of suburban service locations.

The limited new land consumption shows positive approaches towards a compact settlement structure, especially for the Glattal region, but can lead also to buildingrelated, creative and social challenges in individual cases. However, the local aspect of this restructuring process is very different and varies based on the characteristics of the area, in terms of both the structural characteristics and the distribution of uses and development processes with specific key actors.

\section{Conclusions}

The development of the Glattal region and the case studies show that a structured and legitimized growth management (and planning law) contributes to an urban and functional redevelopment of suburban service locations and can improve their quality of place, thus creating integrated districts in a suburban settlement structure with appropriate instruments. Growth management prevents city-centred solutions for urban growth and tries to distribute resources, such as construction land and infrastructure, in a sustainable way while protecting cultural and natural resources. The cantonal structure plan sets a framework to address ongoing growth in the. However, the growth in some areas seems to be too fast, and the pressure is too high in the context of small city structures to adapt to the existing urban structure, as shown in the case studies.

The cantonal level, with its two major responsibilities-definition of central areas in the structure plan and building permissions-is able to strategically develop specific areas and control growth in the inner-city areas. With its power to steer public investments in transport infrastructure, the canton is able to promote certain areas strongly and consequently to create an atmosphere or planning security that facilitates private investments. Interviews with local actors have shown that an institutional organization (such as development agency Glattpark, IG Hochbord) also can promote development processes significantly.

However, it should be pointed out that the cantonal planning level, even with its strong planning instruments, cannot fully control the growth management in the Zürich metropolitan areas. Especially the exceptional market conditions with very low interest rates, lack of investment alternatives to real estate and strong demand on the housing market are allowing a fast and fundamental retrofitting process. After thorough saturation of the office real estate market, many investors (both private and institutional) focused on the housing market, which could also increase the conversion of service locations. There also are some limitations for the cantonal planning when property owner structures are fragmented and a common vision for the future of an area is not shared.

To sum up, the cantonal level in Zürich, with its specific planning instruments, effectively helps to strategically identify areas for retrofitting, create a framework for public and private investments and support the development of these areas over a long period of time. With its authority to give or deny building permission, the canton has strong power to control development up to the detailed urban design level. It is therefore able to develop the metropolitan area-and suburban areas in particular-within a compact mixed-used structure and protect natural and cultural land against an on-going urban sprawl. 


\section{Conflict of Interests}

The author declares no conflict of interests.

\section{References}

Architektengruppe Krokodil. (2013). Glatt! From suburb to city. Zürich: Park Books.

Aring, J., \& Herfert, G. (2001). Neue Muster der Wohnsuburbanisierung. In K. Brake, J. S. Dangschat \& G. Herfert (Eds.), Suburbanisierung in Deutschland (pp. 43-56). Wiesbaden, Germany: VS Verlag für Sozialwissenschaften.

Bengston, D., \& Youn, Y. C. (2006). Urban containment policies and the protection of natural areas: The case of Seoul's greenbelt. Ecology and Society, 11(1).

Bizer, K., Einig, K., Köck, W., \& Siedentop, S. (Eds.). (2011). Raumordnungsinstrumente zur Flächenverbrauchsreduktion. Handelbare Flächenausweisungsrechte in der räumlichen Planung. Baden-Baden: Nomos.

Brake, K. (2005). Der suburbane Raum als Standorttyp. In K. Brake, I. Einacker \& H. Mäding (Eds.), Kräfte, Prozesse, Akteure: Zur Empirie der Zwischenstadt (pp. 8-44). Wuppertal: Müller + Busmann.

Bramley, G., \& Watkins, D. (2014). 'Measure twice, cut once'-Revisiting the strength and impact of local planning regulation of housing development in England. Environment and Planning B: Planning and Design, 41(5), 863-884. doi:10.1068/b39131

Brandl, A., Barman-Krämer, G., \& Unruh, P. (2007). Gestaltungsstrategien für den suburbanen Raum: Wissenschaftliche Annäherung an seine stadträumlichen Qualitäten und Potenziale. disP-The Planning Review, 43(168), 44-55.

Bundesinstitut für Bau-, Stadt- und Raumforschung. (2017). Raumordnungsbericht 2017. Bonn: Bundesamt für Bauwesen und Raumordnung. Retrieved from http://www.bbr.bund.de/BBSR/DE/Ver oeffentlichungen/Sonderveroeffentlichungen/2017/ rob-2017-dl.pdf?_blob=publicationFile \&v=3

Burdack, J. (2006). New economic poles in European metropolitan peripheries: Introductory remarks on theory and empirical evidence. European Spatial Research and Policy, 13(2), 139-150.

Campi, M., Bucher, F., \& Zardini, M. (2001). Annähernd perfekte Peripherie: Glattalstadt/Greater Zürich Area. Basel: Birkhäuser.

De Jong, J. (2014). New suburbanisms. London: Routledge.

Dempsey, J. A., \& Plantinga, A. J. (2013). How well do urban growth boundaries contain development? Results for Oregon using a difference-in-difference estimator. Regional Science and Urban Economics, 43(6), 996-1007. doi:10.1016/j.regsciurbeco.2013.10.002

Dunham-Jones, E., \& Williamson, J. (2008). Retrofitting suburbia: Urban design solutions for redesigning suburbs. Hoboken, NJ: John Wiley \& Sons.

EU Ministers. (2007). Leipzig charter on sustainable European Cities. Leipzig: European Union.
Feindt, P. H. (2003). Metropolregion Hamburg-Anmerkungen zu einer politischen Konstruktion von Raum. In E. M. Döring et al. (Eds.), Stadt-Raum-NaturDie Metropolregion als politisch konstruierter Raum (pp. 39-51). Hamburg: Hamburg University Press.

Garreau, J. (1991). Edge city: Life on the new frontier. New York: Anchor Books.

Gennaio, M. P., Hersperger, A. M., \& Bürgi, M. (2009). Containing urban sprawl-Evaluating effectiveness of urban growth boundaries set by the Swiss Land Use Plan. Land Use Policy, 26(2), 224-232. doi:10.1016/j.landusepol.2008.02.010

Hall, P. G., \& Pain, K. (Eds.). (2006). The polycentric metropolis: Learning from mega-city regions in Europe. Abingdon: Earthscan.

Harvey, D. (1987). The urbanization of capital: Studies in the history and theory of capitalist urbanization. Baltimore, MD: Johns Hopkins University Press.

Harvey, D. (2016). The ways of the World. London: Profile Books.

Hesse, M., \& Leick, A. (2013). Wachstum, Innovation, Metropolregionen. Zur Rekonstruktion des jüngeren Leitbildwandels in der deutschen Raumentwicklungspolitik. Raumforschung und Raumordnung, 71(4), 343-359.

Hoelzel, F. (2014). Eine Frage, Zwei Antworten. In Stadtregionen Planen (Themenheft von Hochparterre, Mai 2014). Zürich: Hochparterre.

Jansen, H., Wünnemann, M., \& Roost, F. (2017). Postsuburban revitalization? Redevelopment of suburban business centres in the Frankfurt/Rhine-Main region. Journal of Urban Design, 22(2), 249-272. doi:10.1080/13574809.2016.1261627

Kanton Zürich. (2014). Raumplanungsbericht 2013. Zürich: kdmz.

Kloosterman, R. C., \& Musterd, S. (2001). The polycentric urban region: Towards a research agenda. Urban Studies, 38(4), 623-633. doi:10.1080/ 00420980120035259

Kraemer, C. (2006). Germany-Urban growth regulation with strong local autonomy. In N. Bertrand \& V. Kreibich (Eds.), Europe's city-regions competitiveness: Growth regulation and peri-urban land management (pp. 153-175). Assen: Royal Van Gorcum.

Kretz, S., \& Küng, L. (Eds.). (2016). Urbane QualitätenEin Handbuch am Beispiel der Metropolitanregion Zürich. Zürich: Hochparterre.

Kühn, M. (2003). Greenbelt and Green Heart: Separating and integrating landscapes in European city regions. Landscape and Urban Planning, 64(1), 19-27. doi:10.1016/S0169-2046(02)00198-6

Kunzmann, K. (2001). Welche Zukünfte für Suburbia? Acht Inseln im Archipel der Stadtregion. In K. Brake, J. S. Dangschat, \& G. Herfert (Eds.), Suburbanisierung in Deutschland (pp. 213-222). Wiesbaden, Germany: VS Verlag für Sozialwissenschaften.

Kurz, D. (2008). Disziplinierung der Stadt. Moderner Städtebau in Zürich 1900-1940. Zürich: gta Verlag. 
Lampugnani, V. M. (2015). Bauen in der Peripherie: Stadt oder Suburbia. Tagungsbericht ETH Forum Wohnungsbau 2015. Retrieved from http://www. wohnforum.arch.ethz.ch/sites/default/files/tagungen /tagungsbericht_lampugnani_def.pdf

Landis, J. D. (2006). Growth management revisited: Efficacy, price effects, and displacement. Journal of the American Planning Association, 72(4), 411-430. doi:10.1080/01944360608976763

Loderer, B. (2001). Die heimliche Hauptstadt. Hochparterre-Zeitschrift für Architektur und Design, 10/2001, 14-21.

Meijers, E. (2005). Polycentric urban regions and the quest for synergy: Is a network of cities more than the sum of the parts? Urban Studies, 42(4), S. 76581. doi:10.1080/00420980500060384

Meili, M. (2013). Preface. In Architektengruppe Krokodil (Ed.), Glatt! From suburb to city. Zürich: Park Books.

Nelson, A. C. (1999). Comparing states with and without growth management analysis based on indicators with policy implications. Land Use Policy, 16(2), 121-127. doi:10.1016/S0264-8377(99)00009-5

Odermatt, A. (1999). Räumlich-soziale Entmischung und die Finanzkrise der Kernstädte: das Beispiel Zürich. Geographica Helvetica, 54(1), 18-28.

Österreichische Raumordnungskonferenz. (2011). Österreichisches Raumentwicklungskonzept "ÖREK 2011". Wien: Geschäftsstelle der Österreichischen Raumordnungskonferenz. Retrieved from http://www. oerok.gv.at/fileadmin/Bilder/2.Reiter-Raum_u._Regi on/1.OEREK/OEREK_2011/Dokumente_OEREK_2011 /OEREK_2011_DE_Downloadversion.pdf

Pallagst, K. (2007). Growth management in the US: Between theory and practice. Farnham: Ashgate.

Pfenninger, R., \& Schregenberger, T. (2013). Glatt. Projekte für eine Stadt im Werden. Zürich: Park Books.

Phelps, N. A., \& Wood, M. (2011). The new postsuburban politics? Urban Studies, 48(12), S. 25912610. doi:10.1177/0042098011411944

Reeds, J. (2011). Smart growth: From sprawl to sustainability. Cambridge: Green Books.

Roost, F. (2013). Stadträumliche Qualifizierung von suburbanen Dienstleistungszentren. Anregungen aus
Japan und den USA [Urban spatial qualification of suburban service centers. Suggestions from Japan and the USA]. In Wüstenrotstiftung (Ed.), Nachdenken über Städtebau - Bausteine für eine Interpretation im 21. Jahrhundert (pp. 169-185). Berlin: DOM.

Schmid, C. (2006). Global city Zürich: Paradigms of urban development. In R. Keil \& N. Brenner (Eds.), The global cities reader (pp. 161-169). Abingdon: Routledge.

Scholl, B. (2015). Bernd Scholl-Switzerland. disPThe Planning Review, 51(1), 76-77. doi:10.1080/ 02513625.2015 .1038076

Siedentop, S., Fina, S., \& Krehl, A. (2016). Greenbelts in Germany's regional plans-An effective growth management policy? Landscape and Urban Planning, 145, 71-82. doi:10.1016/j.landurbplan.2015.09.002

Sieverts, T. (1997). Zwischenstadt- Zwischen Ort und Welt, Raum und Zeit, Stadt und Land. Basel: Birkhäuser.

Soja, E. W. (1996). Thirdspace: Expanding the geographical imagination. Cambridge, MA and Oxford: Blackwell.

Suter von Känel Wild. (2015). Teilrevision Richt- und Nutzungsplanung. Entwicklungskonzept Hochbord. Dübendorf: Stadt Dübendorf. Retrieved from http:// www.duebendorf.ch/dl.php/de/5501589eefdfd/2015 0210-DO-Entwicklungskonzept_Hochbord.pdf

Talen, E. (2011). Sprawl retrofit: Sustainable urban form in unsustainable places. Environment and Planning B: Planning and Design, 38(6), 952-978. doi:10.1068/ b37048

Tang, B. S., Wong, S. W., \& Lee, A. K. W. (2007). Green belt in a compact city: A zone for conservation or transition? Landscape and Urban planning, 79(3), 358-373.

Urban Land Institute. (1998). ULI on the future: Smart growth-economy, community, environment. Washington, DC: Urban Land Institute.

Yang, J., \& Jinxing, Z. (2007). The failure and success of greenbelt program in Beijing. Urban Forestry \& Urban Greening, 6(4), 287-296. doi:10.1016/j.ufug. 2007.02.001

\section{About the Author}

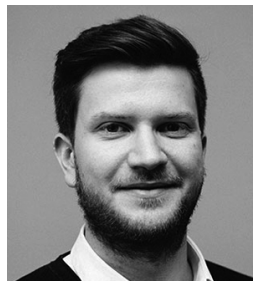

Hendrik Jansen is a doctoral candidate at TU Dortmund University's Department of Urban and Regional Planning and a research associate at ILS-Research Institute for Regional and Urban Development, both located in Dortmund, Germany. He is founder and partner of the urban design office BJP | Bläser Jansen Partner in Dortmund. His research interest focuses on retrofitting post-suburbia, urban design \& policy, and transnational comparison. 